I. М. Демешко

\title{
СТРУКТУРА ВІДДІССЛІВНИХ СЛОВОТВІРНИХ ГНІЗД: МОРФОНОЛОГІЧНИЙ АСПЕКТ
}

Демешко І. М. Структура віддієслівних словотвірних гнізд: морфонологічний аспект.

У статті 3'ясовано морфонологічну будову словотвірних гнізд членованих i нечленованих вершинних дієслів у сучасній українській літературній мові, спрогнозовано можливі морфонологічні зміни, встановлено морфонологічні моделі.

Ключові слова: словотвірна морфонологія, девербативи, словотвірне гніздо, морфонологічні типи, морфонологічні класи. 
Демешко И. Н. Структура отглагольных словообразовательных гнезд: морфонологический аспект.

В статье установлено морфонологическую структуру словообразовательных гнезд членимых и нечленимых вершинных глаголов в современном украинском литературном языке, спрогнозированы возможные морфонологические изменения, установлены морфонологические модели.

Ключевые слова: словообразовательная морфонология, девербативы, словотвірне гніздо, морфонологічні типи, морфонологічні класи.

Demeshko I. M. The structure of verdal word-building units: morphonological aspect.

Morphonological structure of deverbatives of the third morphonological type in modern Ukrainian language is considered in the article. The morphonological models are installed, probable morphonological changes are predicted.

Key words: word-building morphonology, deverbatives, word-building unit, morphonological types, morfonological classes.

Розвиток української словотвірної морфонології на сучасному етапі позначений прагненням до перегляду й уточнення деяких наукових понять, опису та дослідженню формальних ознак мовних одиниць 3 погляду системно-структурної лінгвістики. Ті нечисленні праці з морфонології, зокрема й дисертації, не дають відповіді на ряд надзвичайно важливих для мовознавства питань, зокрема в словотвірній морфонології, таких, як роль морфонологічного чинника у словотвірних процесах, процедурні питання морфонологічного аналізу, морфонологічні особливості комплексних словотвірних одиниць (словотвірних гнізд, їхніх субодиниць (словотвірних парадигм, словотвірних ланцюжків), визначення функціонального навантаження дериваційних засобів, виділення морфонологічних типів і морфонологічних класів дериватів, зокрема девербативів, визначення функціонального навантаження морфонологічних моделей девербативів. В останні роки досить інтенсивно вивчаються словотвірні гнізда, що виконують систематизуючу функцію словотвірного рівня мови, i морфонологічні явища похідних, що супроводжують процес словотворення. У сучасному українському мовознавстві словотвірні гнізда, його субодиниці перебувають у центрі дериватологічних студій (С. А. Карпіловська, В. В. Грещук, М. П. Лесюк, Л. І. Коржик, 3. О. Валюх, М. Ю. Федурко, Г. М. Потапова, Г. В. Пристай). Матеріал, накопичений теоретичним мовознавством і лексикографічною практикою, дозволяє поставити питання про виявлення специфіки словотвірних гнізд (СГ) із вершинним дієсловом. Віддієслівні словотвірні гнізда максимально великі кількісно і різноманітніші за дериваційною семантикою похідних порівняно із гніздами інших частин мови. Дієслова становлять основну словоутворювальну силу будь-якого СГ. Актуальність дослідження визначається необхідністю морфонологічного аналізу словотвірної системи словотвірних гнізд iз вершинними дієсловами. Вивчення конкретних СГ є актуальним для словотвірної типології СГ, опису внутрішньої організації системи словотвору. 
Морфонологічні явища завжди зумовлені морфонологічним контекстом. Словотвірна морфонологія відрізняється від інших лінгвістичних дисциплін тим, що в ній значна частина теоретичних положень залишається дискусійною і не здобула остаточного розв'язання в сучасних лінгвістичних студіях.

Розширення морфонологічної проблематики стає наслідком того, що повнота й адекватність морфонологічного опису знаходиться в залежності від результатів аналізу фонологічного і морфологічного ладу мови, а морфонологічний опис набуває аналітичного характеру, тому дослідження й опис формальних ознак мовних одиниць з погляду системно-структурної лінгвістики залишається актуальним. Труднощі морфонологічного опису пояснюються і тим, що в наукових розвідках зі слов'янської морфонології спостерігаються різні морфонологічні концепції, наявність різних програм аналізу матеріалу, неоднорідність накопиченого матеріалу, а це ускладнює теоретичне узагальнення отриманих результатів. На сучасному етапі розвитку дериватології актуальним залишається створення типології словотвору, в основі якої лежить функціональне навантаження твірних основ різних частин мови. Вивчення таких мікросистем дає можливість виявити «дериваційну валентність різних класів твірних слів, їхні словотвірні потенції і зумовленість дериваційної потенції різних класів їхніми формально-семантичними особливостями, способи освоєння семантичних інгредієнтів твірного слова в семантичній структурі похідного в процесах деривації, парадигматику й синтагматику твірних основ, принципи класифікації й опису похідних за ознаками твірних основ» [5, с. 8].

Метою пропонованої розвідки є з'ясування морфонології СГ із членованими і нечленованими питомими та іншомовними вершинними дієсловами в сучасній українській літературній мові. Досягнення поставленої мети передбачає розв'язання таких завдань: 1) проаналізувати гнізда однотипних дієслів у структурно-семантичному плані; 2) з'ясувати морфонологічну будову словотвірних гнізд членованих і нечленованих вершинних дієслів у сучасній українській літературній мові; 3) спрогнозовати можливі морфонологічні зміни; 4) установити морфонологічні моделі девербативів зазначеного типу.

У дослідженні на основі реєстру дієслів і спільнокореневих слів упорядковано словотвірні гнізда за критеріями, розробленими російськими та українськими мовознавцями (О. М. Тихоновим, Н. Ф. Клименко, Є. А. Карпіловською). Словотвірне гніздо - сукупність слів упорядкованих відношеннями похідності й об'єднаних спільним коренем. Спорідненість слів одного гнізда виражається в подібності форми і значення. Структура СГ ієрархічна, з послідовним підпорядкуванням одних одиниць іншим, що виявляється у співвідношенні слів різного ступеня похідності [9, с. 620]. Проблема встановлення морфонологічної структури віддієслівних СГ ускладнюється відсутністю гніздового словотвірного словника української 
мови 3 переліком усіх вершинних дієслів. Укладання такого словника дає змогу здійснити морфонологічну класифікацію: 1) виявити типові формальні трансформації девербативів на кожному ступені деривації; 2) з’ясувати морфонологічно марковані похідні; 3) виділити спільні й відмінні риси в морфонологічному вияві СГ дієслів різної морфонологічної будови; 4) установити морфонологічні типи i морфонологічні класи СГ iз вершинними дієсловами.

Терміном «морфонологічна структура» СГ позначаємо такі характеристики словотвірних парадигм, які відрізняються конкретними морфонологічними схемами і правилами. До одного морфонологічного класу (МК) належать СГ із морфемно, словотвірно і морфонологічно тотожними вершинними дієсловами, морфонологічними трансформаціями й морфонологічними операціями похідних. Кожен МК характеризується певною контактною зоною, наявністю відповідних морфонологічних змін (усічення твірної основи, консонантні альтернації на морфемному шві, вокалічні в кореневій морфемі, інтерференція, інтерференція, зміна акцентних позицій), позиція палаталізації / депалаталізації, нарощення суфіксальної морфеми. Підтримуємо думку Л. М. Булатової, що між різними класами однорідних парадигм існують відмінності, у залежності від чого вони групуються у загальні класи (типи), яким відповідають більші одиниці типології [1, с. 39].

Не викликає сумніву, що словотвірні можливості слів чітко простежуються на тлі словотвірних гнізд, що являють собою словотвірну мікросистему, «що складається зі словотвірних ланцюжків та парадигм, якими охоплюється вся сукупність спільнокореневих слів, ієрархічно впорядкованих відношеннями похідності та мотивованості» [2, с. 169]. Як засвідчує фактичний матеріал, непохідні слова є словотвірно спроможніші, ніж похідні.

О. М. Зубань зазначає, що формалізм структурної морфеміки посткореневої зони українського дієслова полягає в роздільному моделюванні плану змісту та плану форми посткореневих морфемних структур, що є вимогою системного граматичного опису мови [8, с. 8]. Формальний лінгвістичний опис морфемної структури суфіксальної зони дієслівних основ представлений у вигляді формальної і функціональної формул будови морфемної дієслівної основи. Досліджуючи парадигми суфіксальних морфем дієслівних основ в морфонологічному напрямку, розглянуто аломорфи альтернуючих морфем як альтернанти одного морфонологічного ряду, у якому кожна фонологічна відмінність морфа виконує певну морфологічну функцію. У систему морфонологічних альтернацій контактної зони українського дієслова входять усі голосні фонеми, 22 приголосні фонеми $(\boldsymbol{\sigma}, \boldsymbol{n}, \boldsymbol{\boldsymbol { c }}, \boldsymbol{\boldsymbol { \mu }}, \boldsymbol{\phi}, \boldsymbol{z}, \boldsymbol{⿰ ⿻ ⿰ ㇒ ⿻ 二 丨 冂 , ~}, \boldsymbol{\partial}$, $\left.\boldsymbol{\partial}^{\prime}, \mathbf{3}, \check{\boldsymbol{u}}, \boldsymbol{\kappa}, \boldsymbol{л}, \boldsymbol{л}^{\prime}, \boldsymbol{\mu}, \boldsymbol{H}^{\prime}, \boldsymbol{p}, \boldsymbol{p}^{\prime}, \boldsymbol{c}, \boldsymbol{m}, \boldsymbol{u}, \boldsymbol{u}\right), 4$ фонемосполуки (ва, ну, $\left.\boldsymbol{c m}, \boldsymbol{u} \boldsymbol{u}\right)$.

Словотвірна структура слова втілює в собі той аспект мовного усвідомлення, який пов'язаний i 3 процесами категоризації, i 3 відображенням національно-культурної специфіки мовної картини світу.

ㄷ I. М. Демешко, 2013. 
У зв'язку з цим вивчення мовних одиниць у межах антропоцентричної парадигми, зокрема в етнокультурному аспекті, неможливе без звернення до словотвірного і морфонологічного проміжних рівнів мови. Словотвірна система української мови становить собою дві великі підсистеми. Усі похідні української мови залежно від кореневої (осно́вної) чи формантної спільності діляться на дві групи. Першу утворює коренева (осно́вна) співвідносність похідних - словотвірні гнізда і їхні конституенти: словотвірні парадигми, ланцюжки й пари; друга - базується на формантній співвіднесеності, до якої належать словотвірні типи і категорії. Кожне похідне слово, що входить до словотвірного гнізда, має унікальне лексичне значення, характеризується індивідуальним набором похідних. Аналіз віддієслівних СГ дає змогу зробити висновок, що кількість його похідних прогнозує семантика вершинного слова, його інформаційна наповненість, належність до активної чи пасивної лексики, стильова належність, морфемна структура слова, фіналь кореневої морфеми, ініціаль форманта, установлення словотвірної парадигми похідних (одно-, дво-, три-, чотиризонні).

Словотвірно-морфонологічний аналіз членованих похідних другого морфонологічного типу (МТ-2), основу яких становлять словотвірні гнізда 3 вершинами-дієсловами, для яких характерна альтернація консонантів за твердістю - м’якістю, переміщення наголосу на формант, дає змогу розглянути структуру однотипних СГ. Проаналізовано 198 СГ, у яких вершина - питомі членовані дієслова на одиничну морфонему $\{д\},\{\mathrm{T}\},\{3\}$, $\{\mathrm{c}\},\{л\},\{\mathrm{H}\},\{\mathrm{p}\}$ з основами на $\boldsymbol{- a}-\boldsymbol{-}, \boldsymbol{u}-$.

Відомо, що оскільки дієслова багатозначні, то вони активніше втягуються в процес словотворення. Так, дієслово ходити має 13 значень, словотвірне гніздо (СГ), вершиною якого є дієслово ходити (XI клас), складається із 582 похідних, які нерівномірно розташовані на ступенях деривації: І ступінь - 149, II ступінь - 253, III ступінь - 134, IV ступінь 43, V ступінь - 3. Морфонологічна структура СГ МТ-2 на I-ому ступені словотворення позначена такими консонантними альтернаціями: д//дж (ходи́mu - хо́дж-ен(ий), вхо́дити - входж-а́-ти, ви́ходити -ви́ходж-ен(ий), ви́ходити $^{2}$ (обійти скрізь) - по-вихо́дж-ува-ти, дохо́дити (досягати) доходж-а́-ти, дохо́дж-ен'н'(a) та ін.), д//ж (ходи́mи-хож-а́л(ий), хож-а́й,

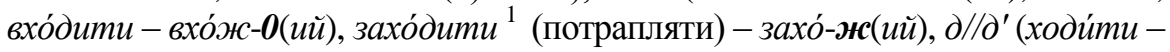
ход'-б(á), ход'-і́льник, ход'-і́н'н'(a), на II-ому ступені деривації позначена консонантними альтернаціями д//жс (ходи́mu - xо́ж-ен'н'(a); на I-ому ступені деривації позначена вокалічними альтернаціями (Ø//V) (xоди́mu ход'-б(á) - ходе́б-ццик), (V//V) (ходи́mu - хі́-л' $(i)$, хі́d-н'(á), входи́mu - вхід-н(и́ŭ), вихо́дити - ви́хід-0, нахо́дити ${ }^{1}$ (оволодівати) - на́хід-0, обхо́дити - обхі́-ник, обхід-н(úŭ) та зміною акцентних позицій (на формант, кореневу морфему або флексію похідного слова в субстантивній, ад'єктивній зонах). Дієслово гасити має 4 значення, словотвірне гніздо (СГ), вершиною якого є дієслово 
гасити (ХІ клас), складається із 111 похідних, які нерівномірно розташовані на ступенях деривації: І ступінь - 43, II ступінь - 42, III ступінь - 25, IV ступінь - 1. Морфонологічна структура СГ МТ-2 на I-ому ступені словотворення позначена такими консонантними альтернаціями: $c / / u$

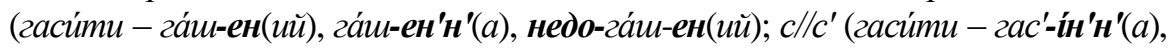
на II-ому ступені деривації позначена консонантними альтернаціями $c / / u$ (3-гаси́mu - згаш-á-тu, зга́u-ен(uй); при-гаси́mu - пригаш-á-mu, пригáu-

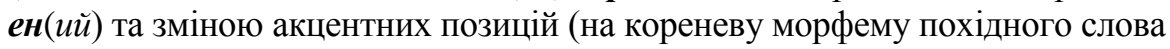
в ад'єктивній зоні, на формант - у субстантивній зоні, на форматив - у дієслівній зоні). Наявність значної кількості похідних говорить про актуальність даних понять, регулярність використання зазначених похідних у сучасній українській літературній мові. Т. І. Вендіна зауважує, що словотворення відкриває широкі можливості для концептуальної інтерпретації дійсності, воно дозволяє зрозуміти, які елементи позамовної дійсності і як дериваційно маркуються, чому вони утримуються свідомістю, адже вже сам вибір того чи того явища дійсності як об'єкта словотвірної детермінації свідчить про його значущість для носіїв мови [3, с. 29].

Отже, словотвірна спроможність твірних основ залежить від їхньої семантичної структури його (інформаційна наповненість, належність до активної чи пасивної лексики, стильова належність), частиномовної належності твірного, ступеня словотворення, морфемної структури слова (непохідні слова словотвірно спроможніші, ніж похідні), фіналі кореневої морфеми, ініціалі форманта, установлення словотвірної парадигми похідних (одно-, дво-, три-, чотиризонні).

Процес деривації уможливлюють морфонологічні операції, які трансформують твірну основу в похідну. Важливим морфонологічним засобом слугує усічення дієслівної фіналі, консонантні i вокалічні альтернації, зміна наголосу. Зазначені морфонологічні трансформації використовуються здебільшого комплексно. До словотвірних гнізд МК-3 належать СГ, у яких вершинні питомі дієслова членовані. Морфонологічна будова фіналі основи вершинного дієслова - тематичний голосний i передньоязиковий приголосний кореневої морфеми.

Морфонологічна структура СГ другого морфонологічного типу

(MT-2) на I-ому ступені словотворення позначена альтернаціями консонантів за твердістю - м'якістю, переміщенням наголосу на формант, кореневу морфему або флексію похідного слова в субстантивній й ад'єктивній зонах. Ці альтернації є диференційними ознаками таких неелементарних

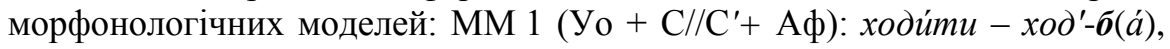
$\mathrm{MM} 2$ (Уо $+\mathrm{C} / / \mathrm{C}+\mathrm{Ac}):$ дохо́дити (досягати) - дохо-дж-а́-mu, MМ 3 (Уо + $\left.\mathrm{C}^{\prime} / / \mathrm{C}+\mathrm{Ac}\right):$ стріля'тu - стріл-о́к, гуді́mu - гуд-о́к, свисті́mu - свист-и́н), MM 4 (Уо + Ac): видава́ти - видав-е́ць $), \mathrm{MM} 5$ (Уо $\left.+\mathrm{C} / / \mathrm{C}^{\prime}+\mathrm{Ac}\right):$ ходи́mи -

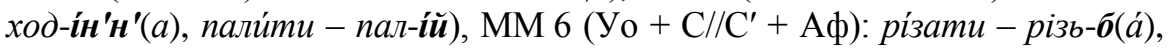


$\mathrm{MM} 7\left(\mathrm{У}_{\mathrm{O}}+\mathrm{C}^{\prime} / / \mathrm{C}+\mathrm{A \kappa}\right):$ обороня'ти - оборо́н-ець $), \mathrm{MM} 8\left(\mathrm{У}_{\mathrm{O}}+\mathrm{V} / / \mathrm{V}+\mathrm{A \Pi}\right)$ : вихо́дити - ви́хід-0), MМ 9 (Уо + C//C' + Ап): зав 'яза́тись - за́в'язь).

Істотною ознакою українського віддієслівного словотворення $\epsilon$ взаємодія морфонологічних позицій, наприклад, усічення, консонантні альтернації і модифікація наголосу (переміщення з тематичного голосного на дериваційний суфікс): сади́mи - саді́ння (д//д'), говори́ти - говорі́ння (р//p'). Палаталізуючу дію на мотиватора можуть мати суфікси -ін'н'- (лагодити - лагодіння, творити - творіння), -ій (водити - водій, возити - возій, носити - носій), -іж⿻ (платити - платіж⿻, падати - падіж). Морфонологічні альтернації розширюють валентні властивості словотвірних морфем, роблять можливими утворення похідних будь-якої словотвірної структури.

Аналіз консонантних морфонологічних альтернацій приголосних у словотворенні в українській мові дає можливість зробити висновок, що консонантні морфонологічні альтернації необхідно описувати для кожного морфонологічного класу приголосних (губних, язикових, фарингальних). Це дає можливість сформулювати морфонологічні правила до цілого морфонологічного класу, а не до індивідуальних одиниць - морфонем. Такий методологічний підхід може визначити регулярність і передбачувати вплив форманта на мотиватора, також передбачувати поведінку приголосних внаслідок сполучуваності з ініціаллю форманта. Таким чином, характер впливу форманта на похідну основу залежить від фонологічної структури суфікса (наприклад, суфікси, що починаються з голосного переднього ряду, впливають на попередній приголосний твірної основи (у більшості похідних), унаслідок чого виникають консонантні альтернації. Так, у творенні членованих питомий девербативів формант -енн-, впливаючи на попередній приголосний твірної основи, призводить до консонантних чергувань (P//Pl) (б//бл, в//вл, м//мл, ф//фл): оздобити - оздоблення, оздоблений, оздоблено; направити - направлення, направлений, направлено; розграфити - розграфлення, розграфлений, розграфлено; питомий суфікс

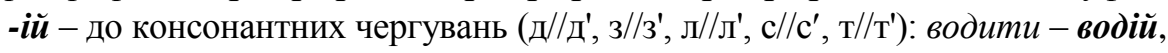
возити - возій, палити - палій, носити - носій, крутити - крутій. Позиція депалаталізації характерна для девербативів на -ок: гудіти - гудок, свистіти - свисток. Девербати на -ець (переселенець, поповненець, обранещь, посланещь, закоханещь) (49), пов'язані з основами пасивних дієприкметників. У творенні похідних відбувається усічення дієслівних суфіксів і нарощення твірної основи.

Уважаємо за необхідне наголосити на тому, що дія форманта на твірну основу певною мірою залежить від його фонологічної структури. Так, якщо ініціаль суфікса складається з голосної переднього ряду /i/, то відбуваються консонантні альтернації $\mathrm{C} / / \mathrm{C}^{\prime}$ (палаталізація приголосного мотиватора), а якщо /e/ - консонантні альтернації P//P1, T//С̆ (пор. возити возіння, платити - платіжк, свердлити - свердлій; розграфити - 
розграфлення; коптити - копчення). Отже, загальною умовою реалізації морфонологічних змін $є$ якість кінцевої фонеми дієслівної основи.

Регулярні консонантні альтернації в українській мові в певних морфонологічних умовах доцільно розглядати не просто як корелятивні пари за твердістю - м'якістю, а як морфонологічні позиції палаталізації. Кожен приголосний в українській мові має різний ступінь палатальності і тому виходячи 3 цього, можна виділити такі класи приголосних, які зазнають змін при словотворенні: I - приголосні, які зазнають часткової палаталізації: $\boldsymbol{ж}, \boldsymbol{u}, \boldsymbol{w}$; II - приголосні, які зазнають палаталізації перед /i/: $\boldsymbol{\delta}, \boldsymbol{m}, \boldsymbol{3}, \boldsymbol{c}, \boldsymbol{u}, \boldsymbol{л}, \boldsymbol{\mu}, \boldsymbol{\partial}, \boldsymbol{p} ;$ III - приголосні, які зазнають перехідної палаталізації (йотації), переважно перед /e/: $\boldsymbol{\sigma}-\boldsymbol{\sigma} \boldsymbol{л}, \boldsymbol{n}-\boldsymbol{n} \boldsymbol{л}, \boldsymbol{\boldsymbol { \sigma }}-\boldsymbol{\boldsymbol { c }} \boldsymbol{\boldsymbol { c }}, \boldsymbol{\boldsymbol { M }}-\boldsymbol{\boldsymbol { \mu }} \boldsymbol{\text { , }}$ $\boldsymbol{\phi}-\boldsymbol{\phi} л$; IV - приголосні, які зазнають перехідної палаталізації (йотації),

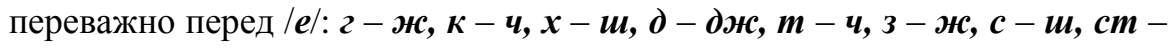
ши. На фонологічному рівні за ступенем палатальності виділяють: 1) власне палатальний: $\check{\boldsymbol{u}}$; 2) палаталізовані: $\boldsymbol{\partial}^{\prime}, \boldsymbol{m}^{\prime}, \boldsymbol{s}^{\prime}, \boldsymbol{c}^{\prime}, \boldsymbol{\mu}^{\prime}, \boldsymbol{\pi}^{\prime}, \boldsymbol{\mu}^{\prime}, \boldsymbol{\partial}^{\prime}, \boldsymbol{p}^{\prime}$; 3) напівпалаталізовані (звуки): $\boldsymbol{\sigma}^{\prime}, \boldsymbol{n}^{\prime}, \boldsymbol{\epsilon}^{\prime}, \boldsymbol{\mu}^{\prime}, \boldsymbol{\phi}^{\prime}, \boldsymbol{\boldsymbol { c } ^ { \prime }}, \boldsymbol{u}^{\prime}, \boldsymbol{u}^{\prime}, \boldsymbol{t}^{\prime}, \boldsymbol{\kappa}^{\prime}, \boldsymbol{x}^{\prime}, \boldsymbol{z}^{\prime}$.

Аналіз морфонологічної структури девербативів другого морфонологічного типу (МТ-2), до якого належать СГ із нечленованими вершинними дієсловами на одиничні тверді морфонеми $\{3\},\{c\}$, для яких характерна альтернація консонантів за твердістю - м'якістю, дає підстави виділити такі комплексні морфонологічні перетворення: 1. Усічення твірної основи паралельно зі зміною акцентної позиції (2 а. п.) (з інфінітивного суфікса -ти наголос переходить на формант): везти́ - вез'$\boldsymbol{i}^{\prime} \boldsymbol{H}^{\prime}(a)$, замести́ - замет'-і́ль. 2. Усічення твірної основи паралельно зі зміною акцентної позиції (3 а. п.) (з твірної основи наголос переходить на флексію): ввід-н(и́ŭ), вивід-н(и́ŭ), завод-н(и́ŭ). 3. Усічення твірної основи паралельно з консонантними альтернаціями і зміною акцентної позиції (4 а. п.) (з інфінітивного суфікса - $\boldsymbol{m и}$ наголос переходить на кореневу морфему): вести́ - ве́д-ен(ий) (с//д), ве́д-ен'н'(а) (c//д). 4. Усічення твірної основи паралельно 3 консонантними і вокалічними альтернаціями: замести́ - замет'-і́ль (с//T'), мịm-л(á) (е//i). 5. Усічення твірної основи паралельно з нарощенням кореневої морфеми: клясти - за-клясти заклин-а́-ти; повзти́ - повз-у́н - повзун-о́к. Адвербіальна зона послуговується, крім суфіксів -y (в-накла́дк-y), -о (докла́дн-о), -ком (повзко́м) суфіксом -ома, що вимагає участі морфонологічних операцій консонантних альтернацій, модифікації наголосу: крадьк-омá.

Однією із характерних особливостей уходження дієслів до словотвірної системи сучасної української літературної мови є вплив їхньої семантики на словотвірні можливості слова. Проблема семантичного нарощення в структурі похідного слова порушувалася Н. Ф. Клименко, В. О. Горпиничем, Т. І. Вендіною, В.В.Грещуком, О. С. Кубряковою, О. К. Безпояско, 3. О. Валюх та ін. Для дієслів характерна транспозиція ㄷ І. М. Демешко, 2013. 
(нова частина мови $з$ новим значенням). Наприклад, це утворення від дієслова

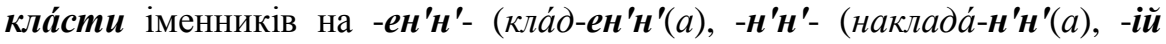
(клад'-і́й), -ник (-льник) (кла́д-ник, наклада́-льник), -к- (докла́д-к(a), накла́д-к(а), -ач (виклад-а́ч), -0 (накла́д-0, окла́д-0), -ість (докла́дн'-ість), -жс- (покла́-жн $(a),-\boldsymbol{и н - ~ ( з а к л а ́ д - и н ( u ) ; ~ п р и к м е т н и к і в ~ н а ~ - о в - , ~ - н - , ~ - с ь к - ~ ( ц ь к - ) , ~}$ -льн-, -ист-: виклад-о́в(ий), докла́д-н(ий), відклад-н(и́ŭ), виклада́-цьк(ий), склада́-льн(ий), вкла́д-ист(ий), дієприкметників на -ен- (кла́д-ен(ий).

Творення девербативів від префіксальних дієслів (на II ступені деривації) є фактом об'єднання в одному словотвірному акті лексичної і синтаксичної деривації, тобто процесом вербалізації і транскатегоризації назв дії до класу іменників: вй-класти - ви́клад-к(a), пере-кла́сти - перекла́d-ен'н'(a), за-везти́ - заве́з-ен'н'(a). Фактичний матеріал підтверджує наявність механізмів впливу на зовнішній вигляд девербативів в українській мові: 1) операція усічення дієслівної фіналі; 2) консонантні і вокалічні альтернації; 3) нарощення суфіксальної морфеми; 4) модифікація наголосу. Трансформації зазнають переважно кінцеві консонанти кореневих морфем.

Основу МТ-2 становлять три- і чотиризонні нечленовані вершинні дієслова на одиничну морфонему $\{3\},\{c\},\{\sigma\}$, для яких характерна альтернація консонантів за твердістю - м'якістю. У творенні девербативів

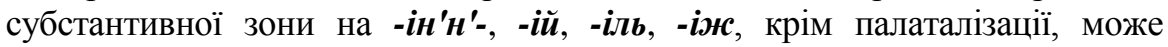
відбуватися і зворотне чергування $\left\{\mathrm{c} \sim д^{\prime}\right\},\left\{\mathrm{c} \sim \mathrm{T}^{\prime}\right\}:\left\{\mathrm{c} \sim \mathrm{T}^{\prime}\right\}$ (9): плести́ плеті́ння, извісти́ - цвіті́ння, масти́ти - масті́ння; \{с $\left.\sim д^{\prime}\right\}$ (8): вести́ веді́ння, пря'сти - пряді́ння; замести́-заметі́ль; кра́сти-кради́юс.

Ці альтернації $є$ диференційними ознаками у творенні девербативів МТ-2 таких регулярний неелементарних морфонологічних моделей: ММ-

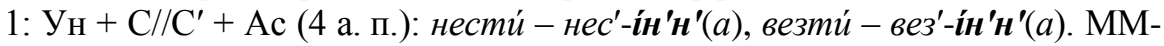
2: $\mathrm{Y}+\mathrm{C} / / \mathrm{T}+\mathrm{Ao}$ (1 а. п.): розкла́сти - розкла́дення (c//д), кла́сти - кла́д-к(a) (c//д), перекла́сти - перекла́дення (c//д), звести́ - зве́дення (c//д), кра́сти кла́д-ен(ий) (с//д), грясти́ - гряд-0(á) (c//д). ММ-3: УН + C//Т' + Ac (4 а. п.):

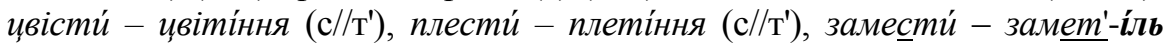
(c//T'), вести́ - веді́ння (с//д'), густи́ - гуді́ння (с//д'), кра́стися - крад'-їй, крад'-ís, (c//д'). Консонантна альтернація $\mathrm{c} / / \mathrm{T}^{\prime}$ виникла ще на праслов'янському грунті внаслідок дисимілятивних змін. ММ-4: У + C//Т +

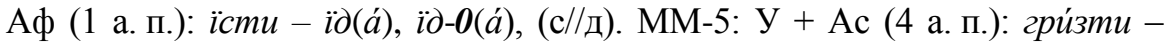
гриз-и́н. ММ-6: Ун + Ас (4 а. п.): повзти́ - повз-и́н. Отже, морфонологічну структуру СГ МТ-2 визначають альтернації C//C', C//T, C//T', які уможливлюють взаємодію обстежуваних дієслівних основ із відповідними формантами i зреалізовані в морфонологічних моделях. Специфіку морфонологічної структури девербативів певного морфонологічного типу визначає морфонологічна операція усічення дієслівної основи, яка взаємодіє з консонантними і вокалічними альтернаціями, які маркують структуру девербативів самостійно або у взаємодії зі зміною акцентної 
позиції. На II ступені деривації морфонологічна операція усічення зазвичай співдіє з консонантними і вокалічними альтернаціями та зміною наголосу при слово- і формотворенні дієслова: замести́ - замет'-і́ль (с//T'), мïm-л(á)

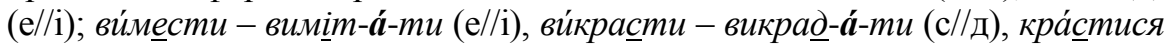
- крад-yчú-сь (с//д). Таким чином, морфонологічна своєрідність СГ залежить від морфонологічної характеристики фіналі вершинних дієслів.

Залучення до процесів віддісслівного словотворення певних механізмів морфонологічних моделей залежить від параметрів поєднуваних твірних основ із формантом. Для контактної зони на межі кореневої і словотворчої морфем необхідно врахувати такі параметри: 1) формальну членованість / нечленованість твірної основи; 2) поскладову організацію кореневої морфеми; 3) клас фінальної морфеми; 4) клас і характер ініціалі форманта.

Суфіксальні морфеми віддієслівного словотворення доцільно характеризувати стосовно їхніх акцентних потужностей, оскільки деякі

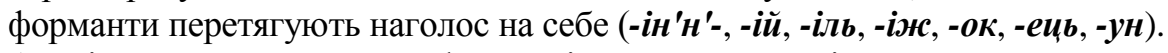
Аналіз консонантних морфонологічних альтернацій приголосних при словотворенні в українській мові дає можливість зробити висновок, що консонантні морфонологічні альтернації необхідно описувати для кожного морфонологічного класу приголосних (губних, язикових (передньо-, задньоязикових), фарингальних). Такий методологічний підхід може визначити регулярність і передбачувати вплив форманта на мотиватора, поведінку приголосних внаслідок сполучуваності з ініціаллю форманта. Морфонологічну кваліфікацію СГ визначають: морфонологічна структура, морфонологічна позиція, морфонологічна трансформація і морфонологічна модель. СГ з вершинними дієсловами розподілено на морфонологічні класи на основі морфонологічної трансформації, яка маркує морфонологічну структуру дериватів відповідної словотвірної парадигми i визначає морфонологічну специфіку кожного класу [7]. На всіх ступенях деривації більше суфіксальних утворень, ніж префіксальних. Фактичний матеріал дозволяє твердити, що питомим дієслівним основам (нечленованим i членованим) і дієслівним основам іншомовного походження (членованим) властива асиметрія морфемної будови [6].

Відсубстантивне походження ряду дієслів підтверджують морфонологічні процеси (морфонологічні альтернації на морфемному шві, зміна наголосу) спільнослов'янської та спільносхіднослов'янської доби. Це чергування глоткової /2/ і задньоязикових $/ \boldsymbol{\kappa} /, / \boldsymbol{x} /$ із шиплячими $/ \boldsymbol{s} /, / \boldsymbol{u} /, / \boldsymbol{u} /$ у позиції перед голосними переднього ряду $\boldsymbol{u}, \boldsymbol{i}$, пор.: друг - дружити, крик кричати, сміх - смішити та ін. «Для великої групи дієслів іменникового походження із суфіксами -a-, $-\boldsymbol{u}$ - характерним є збереження наголосу на тому складі, на який він падає в іменнику: обі́ - обідати, лицемі́р лищемірити та ін. Виняток становлять дієслова, співвідносні з іменниками, які мають наголос на першому складі: щ̧а́стя - щ̧астúmu, ка́ра - кара́ти» 이. М. Демешко, 2013. 
[4, с. 25-26]. Напрямок словотвірної мотивації дозволяє встановити походження лексичної одиниці. Наприклад, слово ліквідація у «Словообразовательном словаре русского языка» О. М. Тихонова (1990), «Українсько-російському словотворчому словнику» 3. С. Сікорської (1995) подається як віддієслівне утворення, а в «Кореневому гніздовому словнику української мови» Є. А. Карпіловської (2002) - це вершинне слово, від якого утворено похідне дієслово ліквідувати. Підтримуємо думку Є. А. Карпіловської, що лексема ліквідувати відсубстантивного походження, на це вказує i походження слова ліквідація (< середньолат. liquidatio - закінчення справи < liquidus - вільний від боргів) (CIC, с. 593).

Фактичний матеріал підтверджує наявність механізмів впливу на зовнішній вигляд девербативів в українській мові: 1) операція усічення дієслівної фіналі; 2) консонантні і вокалічні альтернації; 3) нарощення суфіксальної морфеми; 4) модифікація наголосу. Трансформації зазнають переважно кінцеві консонанти кореневих морфем. Словотвірні гнізда становлять собою культурологічно, ментально марковані одиниці і відіграють важливу роль у формуванні мовної картини світу українського народу. Перспективу подальшого дослідження словотвірної морфонології девербативів убачаємо у встановленні морфонологічних класів словотвірних гнізд із вершинними дієсловами, визначенні різновидів морфонологічних структур у межах кожного класу.

\section{Умовні скорочення}

$\mathrm{MM} \mathrm{-} \mathrm{морфонологічна} \mathrm{модель,} \mathrm{C} / / \mathrm{C}^{\prime}-$ консонантні альтернації передньоязикових приголосних, Т - клас твердих передньоязикових; $\breve{C}$ - клас шиплячих африкат; Р - клас губних, P//Pl - перехідне пом'якшення губних приголосних, Уо - усічення дієслівної основи, А - зміна наголосу (п - префіксальний, к - кореневий, с - суфіксальний наголос; ф- флексійний).

\section{Література}

1. Бромлей С. В. Очерки морфологии русских говоров / С. В. Бромлей, Л. Н. Булатова. М. : Наука, 1972. - 448 с.

2. Вакарюк Л. О. Український словотвір у термінах : [словник-довідник] / Л. О. Вакарюк, С. Є. Панцьо. - Тернопіль : Джура, 2007. - 260 с.

3. Вендина Т. И. Словообразование как способ дискретизации универсума / Т. И. Вендина // Вопросы языкознания. - 1999. - № 2. - С. $27-49$.

4. Городенська К. Г. Словотвірна структура слова (відіменні деривати) / К. Г. Городенська, М. В. Кравченко. - К. : Наук. думка, 1981. - 198 с.

5. Грещук В. В. Український відприкметниковий словотвір / В. В. Грещук. - ІваноФранківськ : Плай, 1995. - 208 с.

6. Демешко I. М. Морфонологічна характеристика словотвірних гнізд з вершинним дієсловом іншомовного походження / I. М. Демешко // Вісник Запорізького національного університету: зб. наук. праць. Філологічні науки. - Запоріжжя : Запорізький національний університет, 2012. - С. 140-145.

7. Демешко І. М. Морфонологія словотвірних гнізд із нечленованими питомими вершинними дієсловами другого морфонологічного типу в сучасній українській мові 
/ І. М. Демешко // Дослідження з лексикології і граматики української мови : зб. наук. пр. / [за ред. проф. А. М. Поповського]. - Дніпропетровськ : Видавець Біла К. О. 2012. Вип. 12. - С. 62-71.

8. Зубань О. М. Морфеміка суфіксальної зони українського дієслова : автореф. дис. на здобуття наук. ступеня канд. філол. наук : спец. : 10.02.01. «Українська мова» / О. М. Зубань. - К., 1997. - 18 с.

9. Українська мова. Енциклопедія / Редкол. : Русанівський В. М., Тараненко О. О. (співголови), Зяблюк М. П. та ін. - К. : Вид-во «Українська енциклопедія» імені М. П. Бажана, 2004. - 821 с. 